\title{
フライ油の使用限界に関する研究
}

一から揚げの食味とフライ油の風味点数—

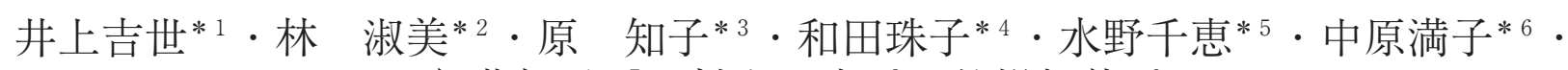
伊藤知子*7 $\cdot$ 村上 恵*8 $\cdot$ 的場輝佳*9

$\left({ }^{* 1}\right.$ 神戸女子短期大学, ${ }^{* 2}$ 園田学園女子大学人間健康学部, ${ }^{* 3}$ 神戸山手短期大学, ${ }^{* 4}$ 大手前短期大学,

${ }^{* 5}$ 甲子園大学栄養学部, ${ }^{* 6}$ 元神戸女学院大学人間科学部, ${ }^{* 7}$ 大阪国際大学人間科学部,

${ }^{* 8}$ 同志社女子大学生活科学部, ${ }^{* 9}$ 関西福祉科学大学健康福祉学部)

\section{Studies on the life span of frying oil Flavor score of frying oil and the taste of fried foods coated with flour}

\section{Sachiyo Inoue ${ }^{* 1}$, Yoshimi Hayashi*2 ${ }^{*}$ Tomoko Hara*3 ${ }^{*}$ Tamako Nishiike-Wada*4, Chie Mizuno* ${ }^{* 5}$, Mitsuko Nakahara*6, Tomoko Fujimura-Ito*7, Megumi Murakami* ${ }^{*}$, Teruyoshi Matoba* ${ }^{*}$}

${ }^{*}{ }^{1}$ Kobe Women's Junior College, 4-7-2, Minatojimanaka-machi, Chuo-ku, Kobe-shi, Hyogo, 650-0046

${ }^{*}$ Faculty of Human Health, Sonoda Women's University, 7-29-1, Minamitukaguchi-cho, Amagasaki-shi, Hyogo, 661-8520

${ }^{* 3}$ Kobe Yamate College, 7-12-1, Nakayamatedori, Chuo-ku, Kobe-shi, Hyogo, 650-0004

${ }^{*}$ Otemae College, 2-2-2 Inano-cho, Itami-shi, Hyogo 664-0861

${ }^{*}$ Koshien University, 10- 1, Momijigaoka, Takarazuka-shi, Hyogo, 665-0006

${ }^{* 6}$ School of Human Science, Kobe College, 4-1, Okadayama, Nishinomiya-shi, Hyogo, 662-8505

${ }^{*}$ Osaka International University, 6-21-57, Tohdacho, Moriguchi-shi, Osaka, 570-8555

${ }^{* 8}$ Doshisha Women's College of Liberal Arts, Teramachi Nishiiru, Imadegawa-dori, Kamigyo-ku, Kyoto, 602-0893

* ${ }^{9}$ Kansai University of Welfare Sciences, 3-11-1, Asahigaoka, Kashiwara-shi, Osaka, 582-0026

$$
\begin{aligned}
& { }^{* 1} \text { 二 650-0046 神戸市中央区港島中町 4-7-2 } \\
& \text { *2 }=661-8520 \text { 尼崎市南塚口町 7-29-1 } \\
& { }^{* 3} \overline{\mathrm{T}} 650-0004 \text { 神戸市中央区中山手通 7-12-1 } \\
& { }^{* 4} \text { ₹ 664-0861 伊丹市稲野町 2-2-2 } \\
& \text { *5 \% 665-0006 宝塚市紅葉ガ丘 10-1 } \\
& { }^{* 6} \text { 个662-8505 西宮市岡田山 4-1 } \\
& \text { *7 } 7570-8555 \text { 守口市藤田町 6-21-57 } \\
& \text { *8 }=602-0893 \text { 京都市上京区今出川通寺町西入 } \\
& \text { *9 } \text { 个582-0026 柏原市旭ヶ 丘 3-11-1 }
\end{aligned}
$$

\footnotetext{
This study clarifies the applicability of a sensory evaluation to easily determine the life span of frying oil on the fried food cooking in the kitchen. Two types of foods, i.e., a chicken fillet and potato, were deep-fried coated with two types of flour, i.e., potato starch and wheat flour. Frying was continued until the flavor score of the oil had dropped to 3. A sensory evaluation of the frying oil and each fried food was then carried out. The life span of the frying oil to reach the flavor score of 3 was slightly
} 
longer for the potato compared to the chicken fillet. It was suggested that the scores for the viscosity and rancid flavor of the frying oil corresponded to the flavor score result of the frying oil. The flavor and taste of the potato fried in the oil with a flavor score of 3 were not good. However, it was difficult to judge the degradation by the appearance of the fried chicken fillet coated with potato starch. The flavor score of the frying oil corresponded to the rancid flavor of the frying food in any case. The color of the frying oil and the taste of the fried materials varied case by case. These results suggest that the flavor score of the frying oil is a useful and easy method to determine the life span of frying oil in the domestic kitchen when a potato starch or wheat flour coating is used.

\section{諸言}

揚げる調理においてフライ油がどの程度まで使用可能 であるかということは, 揚げ物の風味, フライ油の劣化 による毒性 ${ }^{1)}$ の問題，使用基準がつかめないことによる 大量の廃油による環境污染問題などから重要な課題であ る。また, 食用油の原料となる大豆やトウモロコシがバ イオ燃料の製造に使われている現在，食資源の有効利用 の観点からも家庭で揚げ調理を行う際にフライ油の使用 限界を正しく判断することが必要となる。著者らは分析 機器などの設備がない家庭でおいしい揚げ物を作るため のフライ油の使用限界を官能評価により判断する方法に ついて検討してきた。その結果，暫定油脂分析試験法 ${ }^{2}$ による官能評価における風味点数の分類で油自体の風味 点数が 3 になった時点, すなわちフライ油の風味が油っ ぽく，重く，油臭く感じられ，かつ口中での消去性が悪 く感じられた時が油の使用限界の目安となることを動物 性素材の豚ヒレ, 鶏ささ身, いわし, さわら, 植物性素 材のピーマン，じゃがいもを素揚げにした場合，次いで 天ぷら，パン粉揚げといった揚げ方法が異なる場合につ いて明らかにしてきた ${ }^{3-7)}$ 。

本研究では揚げ方法としてから揚げ，すなわち片栗粉 あるいは小麦粉をまぶして揚げた場合にフライ油の使用 限界が油自体の風味点数から判定できるかを検討した。 対照として素揚げを同時に行った。

\section{実験方法}

\section{1. 実験材料}

\section{1) フライ油}

大豆白絞油（J-オイルミルズ製）を使用した。使用 油の化学特性值はケン化価190. 4, カルボニル価 (CV) $2.9 \mathrm{meq} / \mathrm{kg}$, 酸価 (AV) 0.06, 過酸化物価 (POV) $0.0 \mathrm{meq} / \mathrm{kg}$, ヨウ素価 132.8 , 総トコフェロール含量は $95.6 \mathrm{mg} / 100 \mathrm{~g}$ であった。

\section{2 ）揚げ試料の調製}

動物性素材として鶏ささ身を，植物性素材としてじゃ がいも（メークイン）を用いた。前報 ${ }^{6.7)}$ と同様に一定 の処理方法により調製して揚げ種を試料として用いた。
すなわち, 鶏ささ身は $2 \mathrm{~cm}$ 幅の輪切りとし, じゃがい もは $3 \mathrm{~cm} \times 3 \mathrm{~cm} \times 0.8 \mathrm{~cm}$ に調製した。揚げ種に付け る粉の付け方は一定の大きさのビニール袋 $(18 \mathrm{~cm} \times$ $25 \mathrm{~cm})$ に片栗粉または小麦粉を $10 \mathrm{~g}$ 入れ，揚げ種を 1 回分 $50 \mathrm{~g}$ （鶏ささ身 5 個，じゃがいも $6 \sim 7$ 個）ずつ入 れてよく振って粉を付けた。余分な粉をよくはたき落と してから重量を測定し，もとの試料の重量を差し引いて 付いた粉の量を求めた。粉を付けることにより材料の重 量は 1 回分当たり $2 \mathrm{~g}$ 前後増加した。鵎ささ身は, 前日 に粉を付けたものを冷凍し, じゃがいもは実験当日に粉 を付けたものを揚げた。

\section{2. 揚げ方法}

揚げ方法は前報 ${ }^{4-7)}$ に準じた。すなわち，キッチンフ ライヤー（ナショナル NF-F150）を用い, 油500 g を入れ, 水銀温度計をフライヤー中央に固定し, 加熱温度を $170^{\circ} \mathrm{C}$ に設定した。 $170^{\circ} \mathrm{C}$ に到達後, 15 分毎に材料を投入 した。1 回の投入量は素揚げの場合は50 g, 片栗粉揚げ, 小麦粉揚げの場合は揚げ種5 $0 \mathrm{~g} に$ 片栗粉または小麦粉を 付けて油に投入した。揚げ時間は素揚げ，片栗粉揚げお よび小麦粉揚げともに鶏ささ身で 3 分, じゃがいもで 4 分とした。対照として油のみの加熱を同時に行った。

\section{3. 官能評価法}

フライ油の性状および揚げ物の評価を把握するために, 揚げ回数ごとにフライ油の性状として, 油臭さ, 粘度, 色に関して, 揚げ物の性状として外観, 油臭さ, 味, 匂 い，揚がり具合について前報 ${ }^{4-7)}$ と同様に+2（良い） から-2（悪い）の5段階の評点法により評価した。ま た揚げ物の総合的なおいしさを同様に 5 段階で評価し, +2を“おいしい”，＋1を“まあまあおいしい”（嗜好 限界), 一 1 を“がまんして食べられる”(可食限界), ー 2 を“おいしくない”として評価した。フライ油およ び揚げ物は, いずれも室温に冷却後, 官能評価を行った。 また, これと併行し，暫定油脂分析試験法 ${ }^{2)}$ に基づく 5 点満点の風味分類表により評価した。すなわち風味の分 類では，“固有臭があっても淡泊である(新鮮油)”を 5 点, “新鮮油固有の風味に微妙な変化が見られ, かすか に油っぽく感ずる状態”を 4 点, “油っぽく・重く・油 

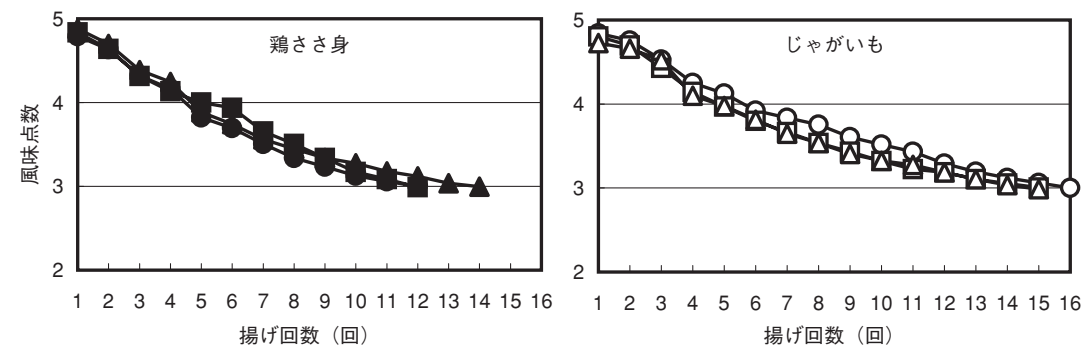

図 1 フライ油の風味点数の变化

：鶏ささ身素揚げ,

○:じゃがいも素揚げ,

口: 䳕ささ身片栗粉揚げ, $\boldsymbol{\Delta}$ : 䳕ささ身小麦粉揚げ

$\square$ : じゃがいも片栗粉揚げ, $\triangle$ : じゃがいも小麦粉揚げ $\quad(\mathrm{n}=18)$

臭く感じられ・かつ口中での消去性の悪い状態”を 3 点, “舌をさすような味・いやなにおいを呈し・かつ非常に 油っぽい状態”を 2 点, “強いいやな臭いを呈する状態” を 1 点としている。揚げ回数ごとにこの点数を記録し， 油の風味が, 油っぽく, 重く, 油臭く感じられ，かつ口 中での消去性が悪く感じられた時点, すなわち風味点数 が 3 になるまでの加熱時間を求めた。この場合，風味点 数 3 の評価の基準として風味点数 3 の基準油を準備して 評価した。パネルは調理関係の教職員 18 名（28～60歳の 女性，平均年齢43歳）で行った。各評価項目で揚げ方法 間の評点の有意差検定はスティール・ドゥワス（SteelDwass）の方法による多重比較を行った ${ }^{8)}$ 。

\section{4.フライ油の劣化度の測定}

揚げ操作をした後に採油した油は，滤過し，冷凍保存 したものについて前報 ${ }^{4-7)}$ と同様に以下の測定を行った。 すなわち, アニシジン価 $(\mathrm{AnV})$, カルボニル価 $(\mathrm{CV})$, 酸価（AV）を基準油脂分析法 ${ }^{9)}$ に準じて測定した。油 の着色度は，基準油脂分析試験法のガードナー法 ${ }^{10)} に$ 従 い測定した。

\section{結果および考察}

\section{1. フライ油の風味点数の変化}

鶏ささ身，じゃがいもをそれぞれ $170^{\circ} \mathrm{C} ， 15$ 分間隔で 揚げ，各揚げ回数ごとのフライ油の風味を風味点数とし て記録し，風味点数が 3 になるまでの変化の過程を図 1 に示す。また，風味点数が 3 になるまでの揚げ回数と加 熱時間および最終の残油量を表 1 に示す。素揚げ，片栗 粉揚げおよび小麦粉揚げいずれの揚げ方法の場合も鶏さ さ身よりじゃがいもの方が風味点数の低下が遅く, 鶏さ さ身では12〜13回，じゃがいもでは15～16回で風味点数 が 3 となった。

油の味に関与する要因については，揚げ材料の成分で ある澱粉は油の味・色・においにほとんど影響を与えず, タンパク質はわずか影響し，グリシンは油の味・色・に おいを著しく変化させることが報告されている ${ }^{11)}$ 。今回 の揚げ試料の鶏ささ身とじゃがいもではタンパク質含量

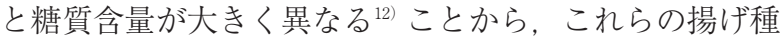
から溶出するアミノ酸13) などの成分が油の風味に影響し
表 1 フライ油が風味点数 3 になるまでの揚げ回数・加熱時 間・残油量

\begin{tabular}{lccc}
\hline 揚げ種 & 揚げ回数 (回) & 加熱時間 $(\mathrm{h})$ & 残油量 $(\mathrm{g})$ \\
\hline 鶏ささ身 & & & \\
$\quad$ 素揚げ & $11.7 \pm 0.6^{\mathrm{a}}$ & $2.9 \pm 0.1^{\mathrm{a}}$ & $484 \pm 7^{\mathrm{a}}$ \\
小麦粉揚げ & $13.3 \pm 0.6^{\mathrm{a}}$ & $3.2 \pm 0.1^{\mathrm{a}}$ & $469 \pm 11^{\mathrm{a}}$ \\
片栗粉揚げ & $12.3 \pm 1.5^{\mathrm{a}}$ & $3.0 \pm 0.3^{\mathrm{a}}$ & $479 \pm 6^{\mathrm{a}}$ \\
じゃがいも & & & \\
素揚げ & $15.3 \pm 0.6^{\mathrm{b}}$ & $3.8 \pm 0.1^{\mathrm{b}}$ & $480 \pm 10^{\mathrm{a}}$ \\
小麦粉揚げ & $14.7 \pm 0.6^{\mathrm{b}}$ & $3.7 \pm 0.3^{\mathrm{b}}$ & $488 \pm 12^{\mathrm{a}}$ \\
片栗粉揚げ & $14.7 \pm 0.6^{\mathrm{b}}$ & $3.7 \pm 0.3^{\mathrm{b}}$ & $490 \pm 13^{\mathrm{a}}$ \\
\hline
\end{tabular}

同一列内の添え字の異なる数值の間には $\mathrm{p}<0.05$ で有意差が あることを示す。（n=3）

たと思われる。各揚げ方法間では, 䳕ささ身とじゃがい も共に素揚げ，小麦粉揚げおよび片栗粉揚げいずれの場 合もほぼ同じ回数で風味点数が 3 になった。

\section{2.フライ油の官能評価}

新鮮油から油の風味点数が 3 になるまでの各揚げ回数 におけるフライ油の油臭さ，粘度および色の官能評価の 評点を図 2 に示す。鶏ささ身では油臭さ，粘度に関して は片栗粉揚げと小麦粉揚げは素揚げより若干評点は高く， 衣を付けることによりフライ油の油臭さ，粘度に関与す る揚げ種成分の油への溶出が抑えられたためと考えられ た。油の風味点数が 3 の時, いずれの評価項目および揚 げ方法でも評点はー1〜-1.9であった。一方，じゃが いもでは，油臭さと粘度に関しては，片栗粉揚げと小麦 粉揚げは素揚げより評価が低かった。この原因として, 揚げ試料の調製で，䳕ささ身は前日に粉を付けたものを 冷凍保存して揚げたが, じゃがいもは実験当日に粉を付 けたものを揚げたため，まぶした片栗粉および小麦粉が とれやすく，一部が揚げ操作中にフライ油に落下し，揚 げ網では取り除くことが出来ず，このカスが油の風味に 影響し，素揚げより評点が低くなったと考えられた。図 1 の風味点数の変化と考え合わせると, フライ油の油臭 さと粘度は，風味点数を判断する要素として関わってい ることが示唆された。

次に，色の評価では，鶏ささ身では，いずれの揚げ方 法でも風味点数が 3 に達した時点では - 1〜 - 1.9で 

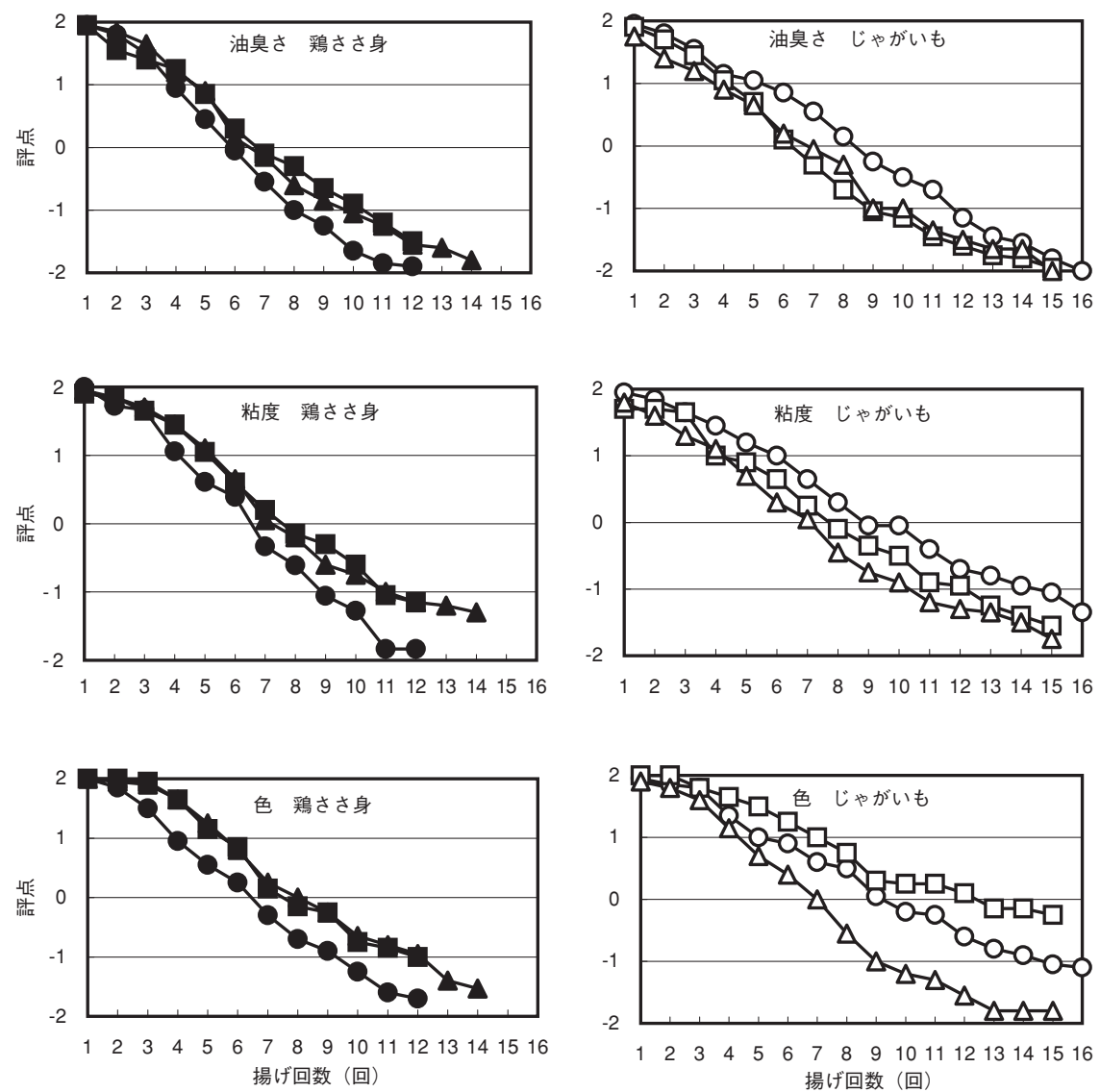

図 2 フライ油の官能評価

: 鶏ささ身素揚げ, 鶏ささ身片栗粉揚げ,

:じゃがいも素揚げ,

$\Delta$ : 鶏ささ身小麦粉揚げ
专

あった。一方，じゃがいもでは，揚げ回数が 8 回目以降 から小麦粉揚げは片栗粉揚げに比べて有意に低い評価で

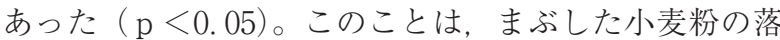
下によりフライ油が白濁してきたことによるものと考え られた。素揚げと片栗粉揚げでは風味点数が 3 に達して いる時点では，色の評点は $0 \sim-1$ で普通からやや悪い 程度であった。油の色への揚げ種の成分の影響としては, 澱粉質食品は油の色にはほとんど影響を与えず，タンパ

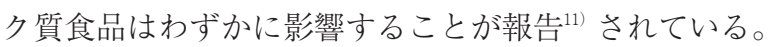
また，タンパク質含有率の高い肉類において，アミノカ ルボニル反応に由来する褐変反応が油の着色に大きく影 響することも報告されている ${ }^{14)}$ 。したがって，図 2 に示 すように鵎ささ身では風味点数 3 になった時点の色の評 点は-1.9と低く, じゃがいも素揚げ, 片栗粉揚げの場合, 風味点数 3 , すなわち使用限界に達しているにも関わら ず色の評点は 0 〜 1 であった。なお，油の色を家庭で のフライ油の使用限界の目安とする報告 ${ }^{15},{ }^{16)}$ があるが 以上のように，フライ油の色は，揚げ種や揚げ方法に左 右されるため，様々な揚げ種や揚げ方法を行う家庭にお いては，使用限界の基準としてフライ油の風味からの方 が判定し易いと考える。

\section{3. 揚げ物の官能評価}

揚げ物の官能評価の評点を図 3-1, 図 3-2 に示す。 鶏ささ身の場合，油臭さの項目ではいずれの揚げ方法で も揚げ回数が多くなるにつれ評点は漸次低下した。しか し, 外観の項目では, 風味点数が 3 の時点では, 片栗粉 揚げの評点は小麦粉揚げの評点より有意に良い評価で

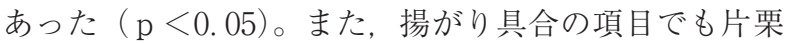
粉揚げの評点は素揚げの評点より有意に良い評価であっ

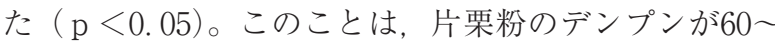
$70^{\circ} \mathrm{C}$ で容易に糊化することに伴い粘度が上昇し ${ }^{17)}$, 揚げ 材料を包み込む膜ができ評点が良かったと考えられる。 しかし，おいしさはー0.5でやや可食限界に近かった。 一方，じゃがいもの場合はいずれの揚げ方法においても 各評価項目で揚げ回数が多くなると評点は漸次低下し, 油の風味点数が 3 に達した時, -1 〜 2 であった。油 の風味点数と揚げ物の評価の関係を見ると, 油の風味点 数が 4 , すなわち, 鶏ささ身およびじゃがいもの揚げ回 数が共に 4 回〜 5 回の時, 揚げ物の油臭さの評点は, 鶏 ささ身およびじゃがいもが共に 1 でやや良い評価であっ た。油の風味点数が 3 の時（鶏ささ身で揚げ回数が 12 13回，じゃがいもで15～16回)，揚げ物の油臭さの評点

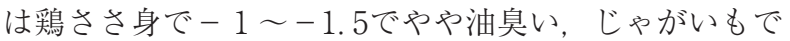
- 2 と悪い評価であり, フライ油の風味点数と揚げ物の 油臭さの評価はいずれの揚げ種, 揚げ方法でも相関関係 

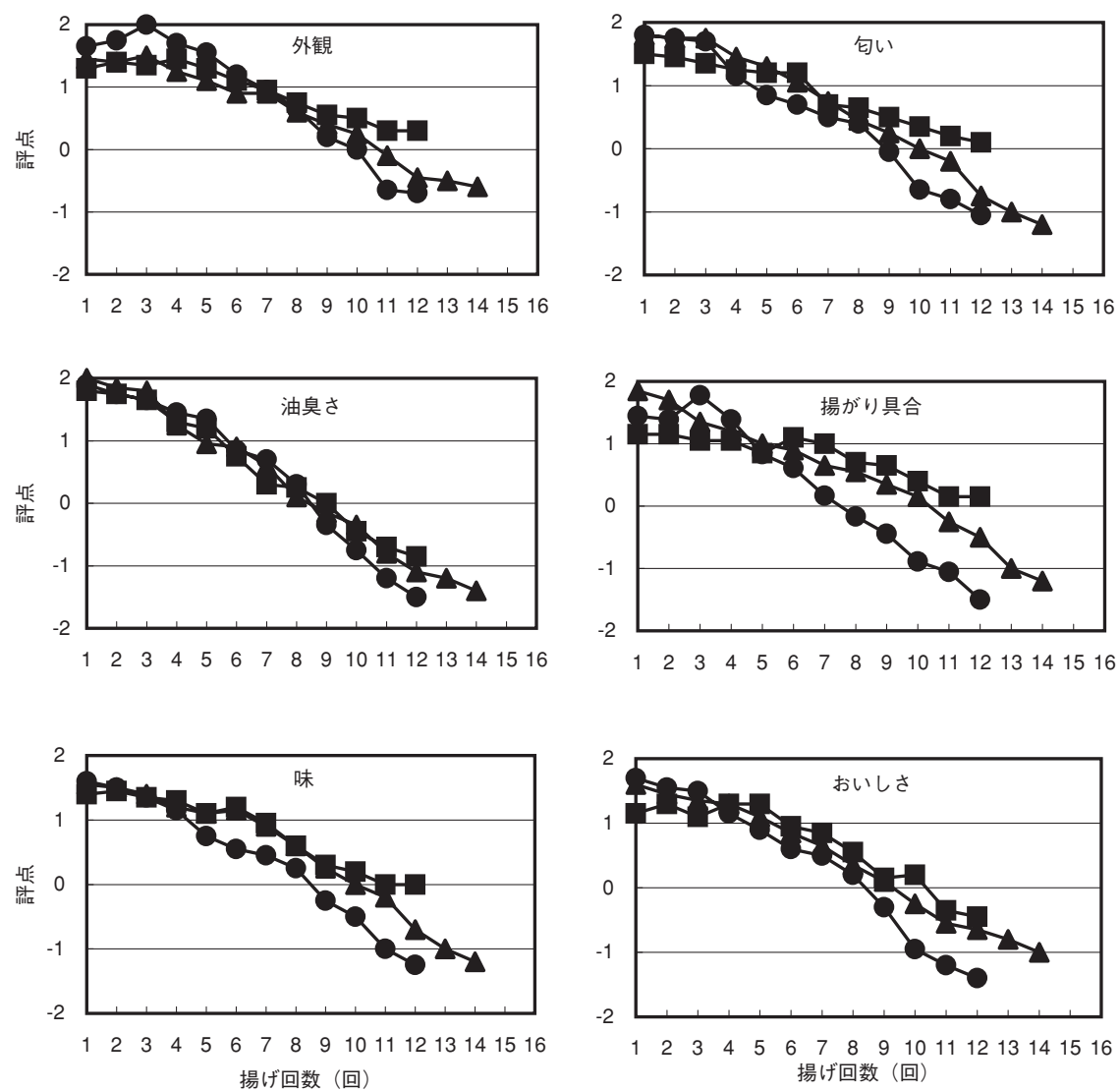

図 3-1 鵎ささ身（揚げ物）の官能評価

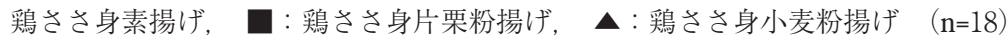

表 2 「風味点数 $3 」$ のライ油の劣化度*

\begin{tabular}{|c|c|c|c|c|c|}
\hline 揚げ種 & $\begin{array}{c}\text { 加熱時間 } \\
(\mathrm{h}) \\
\end{array}$ & アニシジン価 & $\begin{array}{c}\text { カルボニル価 } \\
(\mathrm{meq} / \mathrm{kg})\end{array}$ & 酸価 & 色 \\
\hline \multicolumn{6}{|l|}{ 鶏ささ身 } \\
\hline 素揚げ & 2.9 & $94.8 \pm 4.5^{\mathrm{a}}$ & $12.2 \pm 1.5^{\mathrm{a}}$ & $0.25 \pm 0.02^{\mathrm{a}}$ & $8+$ \\
\hline 小麦粉揚げ & 3.2 & & & & $6+$ \\
\hline 片栗粉揚げ & 3.0 & $137.0 \pm 24.7^{\mathrm{a}}$ & $16.7 \pm 0.5^{\mathrm{b}}$ & $0.20 \pm 0.03^{\mathrm{a}}$ & 6 \\
\hline \multicolumn{6}{|l|}{ じゃがいも } \\
\hline 素揚げ & 3.8 & $149.7 \pm 16.7^{b}$ & $19.0 \pm 0.5^{\mathrm{b}}$ & $0.14 \pm 0.02^{b}$ & 4 \\
\hline & 3.7 & & & & 4 \\
\hline 片栗粉揚げ & 3. 7 & $172.1 \pm 26.9^{b}$ & $21.7 \pm 1.4^{\mathrm{b}}$ & $0.13 \pm 0.03^{\mathrm{b}}$ & $4-$ \\
\hline 新鮮油 & 0 & $0.8 \pm 0.6$ & $2.7 \pm 0.6$ & $0.03 \pm 0.01$ & 1 \\
\hline 空加熱 & 4.3 & $92.2 \pm 3.0$ & $9.0 \pm 1.1$ & $0.08 \pm 0.02$ & $3-$ \\
\hline
\end{tabular}

*単位は「基準油脂分析試験法」による。

同一列内の添え字の異なる数值の間には $\mathrm{p}<0.05$ で有意差があることを示

す。 $(\mathrm{n}=3)$

があった。すなわち，フライ油の使用限界を判定する方 法としては，揚げ物から判断するよりも油自体の風味か ら判断する方が揚げ種や揚げ方法によって左右されず油 の劣化を早く察知出来ると考える。

\section{4.フライ油の劣化度}

風味点数 3 のフライ油のアニシジン価, カルボニル価, 酸価および色の測定結果を表 2 に示す。これら分析值は 油の劣化の指標とされているが, いずれの值も劣化度の 数值は低く食品衛生上問題がないと考えられる。フライ 油の着色度は鶏ささ身素揚げで 8 と高く小麦粉および片
栗粉をまぶしたものは若干低かった。また, 鶏ささ身に 比べて糖質含量の高いじゃがいもでは 4 と低かった。ま た，前報に示したと同様 ${ }^{4 \sim 7)}$, アニシジン価とカルボニ ル価の值は動物性素材の鶏ささ身より植物性素材のじゃ がいもが大きかったが，これら両素材の成分間の大きな 違いがタンパク質含量と糖質含量の差であることから, これらの值は，材料からの溶出成分の影響によると考え られる。すなわち, フライ油の劣化により生じたカルボ ニル化合物は，揚げ物に含まれるアミノ化合物との間で, アミノカルボニル反応を扢こし消費される ${ }^{14)}$ ため, アニ シジン価, カルボニル価が䳕ささ身の方が小さい值と 

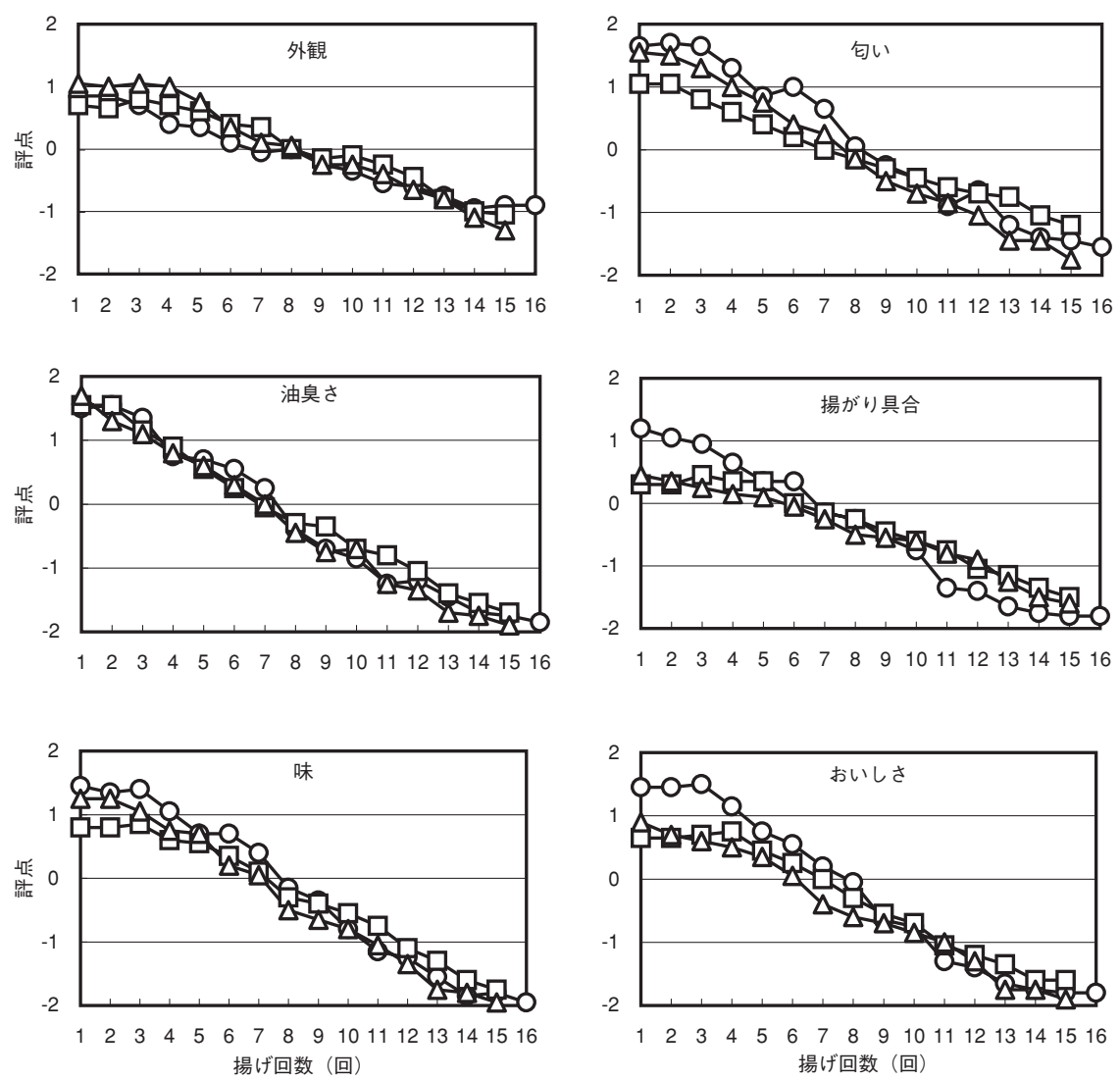

図 3-2 じやがいも（揚げ物）の官能評価

○: じゃがいも素揚げ, $\square:$ : ゃがいも片栗粉揚げ, $\triangle$ : じゃがいも小麦粉揚げ $\quad(\mathrm{n}=18)$

なったと考えられる。

以上の結果から，から揚げの場合も，風味点数 3 のフ ライ油は, 化学分析値からみた限り安全性に問題はない が，風味点数 3 の油で揚げた揚げ物自体は嗜好的な評価 が低下し始める状態であることから，フライ油の使用限 界の判定に油の風味点数 3 を目安に用いることはフライ 油の着色や揚げ種, 揚げ方法の違いに左右されず, 家庭 での簡便な方法として有効であると考えられる。

\section{要約}

動物性素材の鶏ささ身と植物性素材のじゃがいもを用 いてから揚げを行った。それぞれの素材に片栗粉あるい は小麦粉をまぶして揚げた場合に，フライ油の風味点数 が3（油の風味が, 油っぼく, 重く, 油臭く感じられ, かつ口中での消去性の悪い状態）に達した時点を目安に, 油の使用限界を判定できるかを調べ，以下の結果が得ら れた。

（1）油の風味点数の低下は䳕ささ身に比べてじゃがい ものほうが遅かった。

(2) フライ油の官能評価から, 油臭さと粘度の評点の 変化とフライ油の風味点数の変化には相関関係が観ら れたことから, 油臭さと粘度はフライ油の風味点数を 判断する要素として関わっていることが示唆された。 また，フライ油の色は，揚げ種や揚げ方法に左右され るため，使用限界の基準として，フライ油の風味から
の方が判定し易いと考えられた。

（３）フライ油の風味点数が 3 に達した油で揚げた揚げ 物の評価は，じゃがいもでは何れの揚げ方法の場合も 油臭く, 美味しくなかった。しかし, 鶏ささ身片栗粉 揚げの場合，揚げ物の外観，揚がり具合および味の評 価は普通であり，フライ油の劣化の状態と一致しな かった。フライ油の風味点数と揚げ物の油臭さの評価 はいずれの揚げ種，揚げ方法でも相関関係があった。 したがって, フライ油の使用限界を考える際に, 揚げ 物よりもフライ油の風味から判断する方が, 揚げ種, 揚げ方法に左右されず判断し易く, 油の劣化を早く察 知することが出来ると考えられた。

(4) 風味点数 3 のフライ油は, 劣化度の数值から判断 して安全性に問題のない範囲であるが，風味点数 3 の 油で揚げた揚げ物自体は，嗜好的な評価が低下し始め る状態であることから, フライ油の使用限界の判定に 油の風味点数 3 を目安に用いることは, 家庭での簡便 な方法として有効であると考えられた。

\section{文献}

1 ） 大藤武彦, 五十嵐春美, 金田尚志：重合油の構造と栄養 価に関する研究 (第 8 報), 油化学, 21，73-78（1972）

2 ） 日本油化学協会，暫定油脂分析試験法，暫 2-1981（1981）

3) 日本調理科学会近畿支部揚げる・炒める分科会, フライ 油の使用限界に関する研究（I）フライ油と揚げポテトの 
風味に関する合同実験結果, 調理科学, 26, 304-309（1993）

4 ） 日本調理科学会近畿支部揚げる・炒める分科会, フライ 油の使用限界に関する研究（II）揚げ種による違い，日調 科誌, 29, 104-108 (1996)

5 ）日本調理科学会近畿支部揚げる・炒める分科会, フライ 油の使用限界に関する研究（III）フライ油の風味点数と揚 げ物の評価，日調科誌，31，214-219（1998）

6 ）日本調理科学会近畿支部揚げる・炒める分科会, フライ 油の使用限界に関する研究 (IV)「衣揚げ」と「素揚げ」の 比較, 日調科誌, 36, 32-38（2003）

7 ) 井上吉世, 石津日出子, 伊藤知子, 大鹿淳子, 梶本五郎, 竹井よう子, 高村仁知, 中原満子, 西池珠子, 林淑美, 原 知子, 深見良子, 福井広子, 的場輝佳, 水野千恵, 村上恵, 夜久富美子, 湯川夏子：フライ油の使用限界に関する研究 (V) パン粉揚げの場合のフライ油の風味点数と揚げ物の評 価, 日調科誌，36，299-304（2003）

8 ）永田 靖, 吉田道弘: 統計的多重比較法の基礎, サイエ ンティスト社, 東京, 67-70（1997）

9 ）日本油化学協会 基準油脂分析試験法, 2.4.1-83,
$2.4 .12-86, \quad 2.4 .26-81, \quad 2.4 .22-73(1990)$

10）日本油化学協会基準油脂分析試験法, 4.3.1.1-81(1990)

11）島田淳子：揚げ物の品質に関与する要因について（第 5 報)，家政誌，21，364-370（1970）

12）文部科学省科学技術 - 学術審議会資源調査分科会報告「五 訂増補日本食品標準成分表」, 本表編, 女子栄養大学出版部, 26-27, 190-191 (2009)

13）文部科学省科学技術 - 学術審議会資源調查分科会報告「五 訂増補日本食品標準成分表」, 資料編, 女子栄養大学出版部, 120-121，128-129 (2009)

14）古賀秀徳, 利根尚子, 伊藤弘美, 村本信幸, 櫻井英敏, 片山 脩：フライ油性状への揚げ種の影響，日調科誌，31, 24-29 (1998)

15）加藤保子：着色度からみた揚げ油の劣化度, 日食工誌、 40, 433-436 (1993)

16）堀口美和, 大野佳美, 宮川久邇子：一般家庭における揚 げ油の着色抒よび理化学的性状, 日調科誌, 30, 267-271(1997)

17）森田潤司, 成田宏史：食品学総論, 化学同人, 120 (2009) 